\title{
ЛАЗЕРНАЯ ДОППЛЕРОВСКАЯ ФЛОУМЕТРИЯ И ФЛУОРЕСЦЕНТНАЯ СПЕКТРОСКОПИЯ В ОЦЕНКЕ СОСТОЯНИЯ МИКРОЦИРКУЛЯТОРНОГО РУСЛА И ОКИСЛИТЕЛЬНОГО МЕТАБОЛИЗМА У БОЛЬНЫХ САХАРНЫМ ДИАБЕТОМ
}

\author{
Шинкин М.В., Звенигородская Л.А., Мкртумян А.М., Сидоров В.В. \\ ГБУз Московский Клинический Научный Центр имени А. С. Логинова ДзМ, Москва
}

ЦЕЛЬ: изучить состояние микроциркуляторного русла и тканевого метаболизма (по динамике коферментов ФАД и НАДН) методом лазерной доплеровской флуометрии (ЛДФ) и лазерной флуоросцентной спектроскопии (ЛФС) у больных с сахарным диабетом.

МАТЕРИАЛЫ И МЕТОДЫ: ДЛя реализации сочетанного применения методов ЛДФ и ЛФС использовался Аппарат лазерный диагностический «ЛАЗМА СТ» (регистрационное удостоверение Росздравнадзора № Р3Н 2017/5844 от 08 июня 2017 года).

Исследование проводилось на подошвенной части большого пальца стопы, с предварительной обработкой спиртовым раствором поверхности пальца.

Критерии невключения: наличие нарушений магистрального кровотока сосудов нижних конечностей.

Группа контроля: 30 человек. Критерии невключения: наличие онкологических заболеваний, изменения магистрального кровотока нижних конечностей. У пациентов оценивался уровень гликированного гемоглобина $\left(\mathrm{HbA}_{1 \mathrm{c}}\right)$.

РЕЗУЛЬТАТЫ: методом ЛДФ и ЛФС с применением функциональных проб (локальной тепловой и холодовой пробы) было обследовано 40 пациентов с сахарным диабетом в возрасте от 30 до 70 лет: 29 женщин и 11 мужчин. Из них: сахарный диабет 1 типа у 3 человек, сахарный диабет 2 типа у 37 человек.

Пациенты были разделены на следующие группы:

1) Субкомпенсированные нарушения:

1 - микроциркуляция активная, окислительный метаболизм снижен: 14

$2 \mathrm{~b}$ - микроциркуляция неактивная, окислительный метаболизм снижен: 4

3с - микроциркуляция активная, окислительный метаболизм снижен выраженно: 9

2) Умеренные декомпенсированные нарушения микроциркуляции и окислительного метаболизма: 11

3) Выраженные декомпенсированные нарушения микроциркуляции и окислительного метаболизма: 2.

Выводы: выявлена прямая корреляция между показателями $\mathrm{HbA}_{1 c}$ и степенью нарушений микроциркуляторного русла и окислительного метаболизма: в группе №1 $\mathrm{HbA}_{1 c}$ в пределах 6,5-7,2\%; в группе №2 $\mathrm{HbA}_{1 с}$ в пределах 7,5-10,2\%; в группе №3 $\mathrm{HbA}_{1 \mathrm{c}}$ в пределах 10,7-12,1\%. 